$7-1-2016$

\title{
Global Economic Integration In Developing Countries: The Role Of Corruption And Human Capital Investment
}

Charles E. Bryant

Cleveland State University, chuckbryant@csuohio.edu

Rajshekhar G. Javalgi

Cleveland State University, r.javalgi@csuohio.edu

Follow this and additional works at: https://engagedscholarship.csuohio.edu/bus_facpub

Part of the International Business Commons

How does access to this work benefit you? Let us know!

Publisher's Statement

The final publication is available at Springer via http://dx.doi.org/10.1007/s10551-014-2490-3

\section{Original Published Citation}

Bryant, C.R. \& Javalgi, R.G. (2016). Global economic integration in developing countries: The role of corruption and human capital investment. Journal of Business Ethics, 136(3), 437-450. doi: 10.1007/ s10551-014-2490-3

This Article is brought to you for free and open access by the Monte Ahuja College of Business at EngagedScholarship@CSU. It has been accepted for inclusion in Business Faculty Publications by an authorized administrator of EngagedScholarship@CSU. For more information, please contact library.es@csuohio.edu. 


\title{
Global Economic Integration in Developing Countries: The Role of Corruption and Human Capital Investment
}

\author{
Charles E. Bryant · Rajshekhar G. Javalgi
}

\begin{abstract}
Globalization is multifaceted and involves the interaction among businesses, services, governments, and societies beyond national borders. As a result, the flow of foreign direct investment (FDI), international trade in goods and services, and the economic interdependence of the nations of the world have been increasing. At the same time, much attention has been paid to the effect of corruption prevalent within many cultures and societies, and its impact on the economies, especially developing economies. This paper examines the relationship between human capital investment, the level of national corruption, and the global economic integration (GEI) of a nation in developing countries. Based on the data collected from over 60 countries, and building on the FDI and human capital theories, it was found that human capital investment and corruption are related to GEI. It was also found that the level of corruption moderates the relationship between human capital investment and GEI of developing economies. The findings of the study can help to deepen our understanding of GEI and have practical implications for developing countries in terms developing human capital, which plays a critical role in today's knowledge-based economy.
\end{abstract}

Keywords Corruption - Foreign direct investment . International trade - Global economic integration · Human capital investment

\footnotetext{
C. E. Bryant $(\bowtie) \cdot$ R. G. Javalgi

Monte Ahuja College of Business, Cleveland State University, Cleveland, OH 44115, USA

e-mail: chuckbryant@mac.com

R. G. Javalgi

e-mail: r.javalgi@csuohio.edu
}

\section{Introduction}

Globalization is arguably the most popular concept used to describe the economic interconnectedness of nations around the world. It occurs at multiple levels and thus must be conceptualized and defined at each level. A review of the extant literature on globalization reveals three units of analysis that have been researched: Firm level, industry level, and national level (Akhter 2004). At the firm level, globalization is seen as the "process through which firm's move toward integrated network structures" (Malnight 1995). At this level, the degree of globalization is usually referred to in terms of a financial measure such as foreign sales to total sales. At the industry level, Porter defined globalization as "a series of linked domestic industries in which rivals compete against each other on a truly worldwide basis" (Porter 1986). As an example, Morrison and Roth (1992) used measures such as level of international trade, worldwide product standardization, and the presence of key competitors in all key global markets, as measures of industry level globalization.

At the national level, globalization incorporates political, social, and economic interactions (Holm and Sorenson 1995). Harris (1993) defined national level globalization as "the increasing internationalization of the production, distribution, and marketing of goods and services". Akhter (2004) conceptualized economic globalization as "a process that results in increasing integration of a country's economy with the rest of the world". Economic globalization comprises the globalization of markets, production, technology, industries, and corporations. Developed countries are integrating with developing countries by means of foreign direct investment (FDI), reduction in trade barriers, and changes in political landscape. 
While the economic, social and political impacts of globalization have been argued extensively in both the literature and by governmental commissions (Calomiris 2000; Holm and Sorenson 1995; Meltzer 2000; Mikesell 2001; Sachs 2000; Sorensen 2002; Weithöner 2006), and even protested at the Word Trade Organization (WTO) meetings, there is substantial research indicating the positive benefits of being economically integrated. Recent research on the benefits for nation states becoming more globally connected indicates positive economic benefits both the host and home economies. (Akhter 2004; Akinola 2012; Chang and Lee 2011).

According to the extant literature, the two primary factors impacting economic interconnectedness of a nation are: (1) FDI, (2) international trade (Akhter 2004; Rugman and Verbeke 2004; Rugman 2001). We build on this concept by defining global economic integration (GEI) of a nation as a multidimensional construct comprised international trade (as measured by the exports of goods and services) and foreign direct investment (as measured by inward FDI). It is the national level of GEI with which this present work is concerned.

One of the challenges facing national leaders and policy makers, especially in developing countries, is to increase the level of GEI of their economies by increasing international trade and FDI inflows. Due to liberalization and globalization, a country's economy is much more associated with such country specific factors as investment in human capital and corruption. A nation's, especially a developing nation, integration into the global economy largely depends on its sustained economic growth, which is inextricably connected to such internal factors as human capital development and the level of corruption.

Thus, motivated by the above-mentioned issues, conducting a study on the effects of human capital investment and corruption on the GEI of a nation is of great significance in this globalized era. However, there is a lack of research on the relationships among investment in human capital, national level corruption, and the GEI of a nation. This paper attempts to close that gap.

This paper offers an empirical investigation of the impact of human capital investment and corruption on the GEI of a nation. More specifically, our primary objectives in this paper are (1) to provide evidence that investment in human capital has a positive impact on GEI, (2) to provide evidence that corruption negatively impacts GEI, and (3) to provide evidence that national level corruption moderates the relationship between human capital investment and GEI.

The remainder of this paper is organized as follows: the first section provides the foundational theories on which we build our conceptual argument regarding the relationships among human capital investment, corruption, and GEI. The second section presents literature review and hypothesis development. The third section details the methodology used in hypotheses testing and discusses the overall results. The final section provides a conclusion and offers insight into the implications of this research.

\section{Theoretical Underpinnings}

This current research focuses on the interrelationships between GEI, corruption, and human capital investment. We define GEI as a multidimensional construct consisting of two factors: inward FDI and international trade. As such, the theories underlying our GEI construct are based in FDI theory and international trade theory. These theories, along with human capital theory, provide the foundation for this research and are the focus of this section.

\section{FDI Theory}

Much of the theoretical work in the field of FDI stems from the economics foundation laid by Coase (1937) and Bain (1956). A primary research for establishing the field was Hymer's (1976) work, in which he fundamentally changed the focus of international investment away from neo-classical economics, which assumed the motivation for international investment to be interest rate differentials, and toward the multinational enterprise (MNE) as the foundation for FDI (Dunning and Rugman 1985).

For the purpose of this work, we are interested in the motivations for FDI as would be required to better understand GEI of a nation. Thus, we will rely primarily on the work by Dunning (1980, 1988, 1993). Dunning's Eclectic Paradigm (commonly referred to as the OLI paradigm) for International Involvement, emphasizes three components for FDI motivation: ownership advantage (O), location advantage (L), and internalization advantage (I). Dunning (1980) states that ownership advantages come in the form of both physical advantages such as technological, as well as intangible advantages such as knowledge management. He also incorporated into his ownership advantages, benefits he termed "Transaction Cost Advantages"-advantages that accrue to an MNE through the process of being international-such as knowledge of global markets and the benefits of risk-diversification (Dunning 1993). The locational (or country specific) advantages are linked to the "endowments specific to the countries in which they operate" (Dunning 1980). These location specific endowments, which are categorized into three groups (economic, political, and social), provide comparative advantages due to the host country's specific characteristics. MNE's gain these location specific endowments when they acquire ownership in specific countries. Internalization (I) provides 
the final leg of the OLI paradigm in which, Dunning (1980) answers the question of "why" an MNE would elect to use its ownership advantages instead of selling or leasing these to a firm in the local market. MNE's will internalize production rather than externalize it when market imperfections create an opportunity, which the MNE can exploit by utilizing its own internal resources. These market imperfections can include uncertainty regarding price and availability of supplies, as well as high costs of enforcing property rights.

The OLI paradigm seeks to connect ownership and internalization theories with location advantage, using the idea that once an MNE decided to internalize certain ownership advantages, the MNE needed to decide on the location of that process. This decision is influenced by the natural endowments of the country, but also by the institutional, legal, political, and cultural environments (Dunning 1993). In light of this, Voyer and Beamish (2004) note that the trust and commitment that are necessary for building international operations are compromised in the presence of corruption As such they extend the utility of the OLI paradigm by introducing the notion of corruption and its influence on FDI. Further, Boddewyn (1988) notes that an MNE can reduce the uncertainty associated with foreign operations by better understanding the issue of corruption. Habib and Zurawicki (2002), identify corruption as exerting a strong influence on inward FDI-thus impacting the locational decision $(\mathrm{L})$.

The relationship between corruption and FDI has been well documented in the literature (Al-Sadig 2009; Habib and Zurawicki 2002; Mauro 1996, 1997; Peng and Beamish 2008; Voyer and Beamish 2004). To understand the impact that corruption has on FDI, we must first understand corruption. Researchers agree that corruption has many definitions and can be viewed differently depending on the context. Transparency International (TI) summarizes the economic impact of corruption as: "Corruption constitutes a major obstacle to democracy and the rule of law ... Accountable political leadership cannot develop in a corrupt climate ... Corruption leads to the depletion of national wealth ... Furthermore, it hinders the development of fair market structures and distorts competition, thereby deterring investment (TransparencyInternational 2010). For the purpose of this study, we look at corruption in the public sector and use the following definition from TI as the basis for our work. "Corruption is operationally defined as the abuse of entrusted power for private gain. TI further differentiates between "according to rule" corruption and "against the rule" corruption. Facilitation payments, where a bribe is paid to receive preferential treatment for something that the bribe receiver is required to do by law, constitute the former. The latter, on the other hand, is a bribe paid to obtain services the bribe receiver is prohibited from providing" (Transparency-International 2010).

In order to attract FDI, a country must have an investment climate (including licensing systems, infrastructure, and tax systems) that is conducive to foreign investors. Investors often judge the desirability of a developing investment climate through the level of perceived corruption in the government (Mauro 1997). Thus, the perceived level of corruption has a dramatic impact on foreign investment. Corruption is like a two edged sword: it reduces the level of investment and thus economic growth.

Another theory that is relevant to the current article is international trade theory, which is presented below.

\section{International Trade Theory}

Tracing back the evolution of what today is recognized as the standard theory of free trade takes us back to the years between 1776 and 1826, which respectively mark the publication of Adam Smith's Wealth of Nations and David Ricardo's Principles of Political Economy. Free trade, as opposed to the mercantilist policies of protection, was championed at the theoretical level, by both Smith and Ricardo as a route to achieve production efficiency at a global level. In the decades that followed, scholars pursued both theoretical and empirical work to better understand the impact of trade on a nation's economy.

By the early 1980s, the classical models of free trade were debated from different quarters. The major efforts to restructure the free trade doctrine were made in the new trade theory literature. The key contribution of the new trade theory was to discard the limiting assumptions of the traditional trade theory: the absence of scale economies in production, and the assumptions of homogeneous products and perfectly competitive markets in exchange. These three aspects-scale economies, imperfect markets, and product differentiation-which differentiate the new trade theory from the old trade models, effectively challenge the capacity of the old models as a predictor of the trade pattern across nations on the basis of pre-trade commodity and factor prices as determined by relative endowments. The introduction of returns to scale, which was a major departure of the new trade theory, influenced both the predictability of trade patterns as well as the benefits from trade to the trading countries. The issues of international trade and economic growth have gained substantial importance with the introduction of trade liberalization policies in the developing nations across the world. International trade and its impact on economic growth crucially depend on globalization.

In sum, while international trade has been present throughout much of history, its economic, social, and political importance has become more impactful in recent 
decades. Industrialization, advanced in technology transportation, globalization, multinational corporations, and outsourcing are all having a major impact on the international trade system. Also, empirically, there appears to be good evidence that international trade affects economic growth positively by facilitating capital accumulation, industrial structure upgrading, technological progress and institutional advancement (Dollar 1992; Lee 1995; Maizels 1968; Wagner 2007).

Finally, in this section, another theory that is relevant to our study is the human capital theory, which is discussed below.

\section{Human Capital Theory}

The theory of human capital can be traced back to John Stuart Mill and Alfred Marshall, both of whom conceptualized the idea of labor productivity being a result of the capital required to develop it (Sweetland 1996). However, it was the more recent work of Mincer (1958), Schultz (1961), and Becker (1960, 1993), who are largely credited with developing human capital as a field of inquiry.

Mincer (1958) developed an empirical model expressly designed to measure the economic impacts of training. He found that the economic gains that were sacrificed for years invested in training were compensated with higher lifetime earnings. Basically, he saw that time spent in training was indeed an investment with a lifetime economic benefit.

Schultz (1961) agreed with Mincer (1958), and introduced the idea that education was a form of capital. He posed that the useful skills and knowledge acquired by people was a form of capital and that this capital "was a product of deliberate investment" (Schultz 1961). Schultz also noted that expenditures were either consumed or invested - which reflected the thinking of Pigou (1928), who was the first to use the term "human capital." Schultz (1961) further extended the current thinking by posing that a higher allocation of expenditures to investment (as opposed to consumption) would produce a greater rate of return. He found that "the income of the US had increased at a higher rate than the combined amount of land, manhours worked, and the stock of reproducible capital used to produce the income". With this, he challenged economists to find the reason for this seeming inequality. This challenge thus became the foundation for the theory of human capital.

Following Schultz, Becker (1960) studied the lifetime economic benefits of a college education when compared with a high school education. His initial work on human capital found that "direct" returns did not justify increased expenditure in education (Becker 1960). However, his later work (Becker 1993) showed evidence to the contrary. In 1975, Becker developed the idea of separating human capital investment into two distinct studies: (1) general purpose human capital investment and (2) firm specific human capital investment. The former-general purposeis generally applicable across the industry. It increases the marginal productivity of the individual by increasing the value of the individual to the industry firms. Thus the firm paying the highest wage will thus attract the best talent. The latter type of investment-firm specific-is not generally applicable across the industry. It increases the marginal productivity within a firm without increasing the marginal productivity to other firms. Thus, the firm bears the cost for specific training (Becker 1975, 1993).

Beckers' idea of different types of training confirms the earlier work of Mincer (1958) who presented the idea that inter-occupational wage differentials were a result of training (general purpose), while intra-occupational wage differentials were a result of experience on the job (specific) (Mincer 1958).

Through the work of Mincer, Schultz and Becker, two central themes emerged that ultimately resulted in creating human capital as a field of inquiry: (1) that economic growth could not be fully accounted for by conventional economic measurement; and (2) that increased levels of education seemed to account for increased personal income (Sweetland 1996).

Subsequent to the foundational work, the importance of human capital investment to national economic growth is supported by various empirical research. The effects of total investment in human capital are directly related to increased GDP in developing nations (Effiok et al. 2012), and in developed nations (Olimpia 2010). Further, empirical research supports economic growth from both formal education systems and informal training system (Galor and Moav 2004; Glaeser et al. 2004; Lucas 1988).

\section{Literature Review and Hypothesis Development}

\section{The Relationship Between Corruption and GEI}

The effects of corruption on the economic activities of a nation have received much attention in the literature. Mauro (1996) studied the impact of host country corruption on economic growth. He found that corruption [measured by the Business International (BI) index] lowered private investment and thereby reduced economic growth. He also found that corruption is strongly and negatively correlated with the investment rate regardless of level of "red tape" of the host country. He also found that corruption lowers the profit on invested capital and would therefore agree with Al-Sadig (2009) that corruption acts as a tax on profits. 
Mauro (1997) investigated the possible causes of corruption in the public sector and followed with potential consequences. He lists five primary regulatory causes and two additional causes that are not associated with government regulations. Five regulatory causes are: (1) trade restrictions (2) government subsidies, (3) price controls, (4) multiple exchange rate and foreign exchange allocation schemes, and (5) low wages in the civil service. And two non-regulatory causes are: (1) natural resource endowments and (2) sociological factors.

To these causes, Mauro (1997) follows with consequences that result from the corruption. In general, he finds the following consequences in the presence of corruption: "Corruption lowers investment and retards economic growth, talent is misallocated; reduces the effectiveness of aid flows, governments loose tax revenue, adverse budgetary issues, quality of infrastructure and public services, distorted composition of government expenditure."

Mauro (1997) also adds to this list of consequences ideas about the extent to which corruption affects investment and economic growth, and provides insight into how corruption influences governments' spending decisions. According to Mauro, "the amount of corruption is negatively linked to the level of investment and economic growth" and further "An improvement of a single standard deviation increases investment by more than $4 \%$ points and the annual growth rate of per capita GDP by more than a $0.5 \%$ ". Additionally, Mauro concluded that bribes can be more readily collected on certain types of government projects (larger over smaller) and that corruption leads to high capital expenditures on white elephant projects.

Wei (2000) investigated the impact of corruption on the ability of an economy to attract FDI. He found that increasing tax on foreign MNC's or increasing the perceived level of corruption both significantly reduced inward FDI. He also studied the impact of the US. Foreign Corrupt Practices Act (FCPA) on US investors. He found that in spite of the US FCPA, US investors were no more averse to corruption than investors in countries without a policy against corruption in foreign economies.

Habib and Zurawicki (2002) performed an econometric study in which they analyzed both the impact of corruption on bilateral FDI flows, and the impact of the absolute difference in home/host country corruption levels on foreign investment. Their study suggests that the level of perceived corruption (as measured by Transparency International's CPI) is indeed significant and negative in regards to bilateral FDI flows. The study also suggests that greater absolute differences in perceived corruption levels from home country to host country, significantly impacts the level of bilateral investment between the two countries. This later point suggests that the investor has gained experience in managing the level of corruption in the home country and is somewhat comfortable in managing the same level of corruption in a foreign country. However, greater levels of perceived corruption in the host country (vis-à-vis the home country) create an unfamiliar investment environment that negatively impacts the decision to invest.

Voyer and Beamish (2004) conducted an econometric study in which they analyzed nearly 30,000 Japanese investments in 59 countries. They found that the inclusion of a corruption index (CPI) into the model increased the predictive power of GDP per capita-so Japanese outward FDI is correlated with host-level corruption. Second, they found that the type of economy is significant as a predictor of Japanese FDI. For industrialized economies, the perceived level of corruption was not significant. However the perceived level of corruption became significant when testing emerging economies.

Al-Sadig (2009) studied the impacts of corruption on host country inward FDI. He found that corruption is a tax on profits and that a 1-pt increase in the corruption level (as measured by ICRG) reduces per capita FDI by $11-20 \%$. However, he also found that the presence of quality institutions had a greater impact on inward FDI than did corruption. Therefore he concluded that a host country may have greater perceived corruption and still attract FDI if the quality of its institutions were perceived as high.

Given the evidence supporting the negative relationship of corruption on foreign investment, it would seem obvious that corruption is a hindrance to an expanding economy. However, not all researchers concur that the relationship between corruption and inward FDI is negative. A series of articles suggest inconclusive evidence, and a discussion a few articles is presented below.

Peng and Beamish (2008) for example, discussed the inconclusive studies regarding the impact of corruption on FDI. Habib and Zurawicki (2002), Mauro (1995, 1997), Voyer and Beamish (2004), Wei (2000), Wu (2006); all found that corruption had a negative impact on FDI. However, Delios et al. (2006), Hines (1995), and Wheeler and Mody (1992) could not confirm a negative relationship between corruption and inward FDI. Further complicating the study is the findings by Robertson and Watson (2004) implying that changes in FDI may actually cause corruption. And finally, Dreher and Gassebner (2011) provide evidence to support the "greasing the wheels" hypothesis, that corruption actually has a positive effect on start-up business when national level regulations are extreme. Based on the above discussion, we propose the following hypothesis:

H1 The higher the level of perceived corruption in a developing economy, the lower the level of GEI in that economy. 
The Relationship Between Human Capital Investment and GEI

The relationship between human capital investment and economic (GDP) growth is strong and widely supported in the literature. Effiok et al. (2012) investigated the relationship between human capital investment and GDP in Nigeria. Their study pointed out that the greater the investment in human capital the greater the level of economic growth (GDP). The relationship was positive and significant. Galor and Moav (2004) compared the ability of human capital investment to generate GDP with the ability of physical capital investment to generate GDP. The study was aimed at finding the impact of replacing industry with knowledge as industrialized nations progressed through the economic growth cycle. Their results agree with Effiok et al. (2012) that human capital accumulation was a prime engine of national economic growth. Using the same basic argument, Glaeser et al. (2004) found that human capital was more important than institutions in generating economic growth; O’Mahony (2012) found that human capital formation in the form of continuous learning (in addition to formal education only), contributed significantly to a nation's economic growth; and Olimpia (2010) developed a measure of the market value of human capital investment in OECD countries, finding that while efficiency varied across countries, investment in human capital contributed to increased GDP growth.

Trade integration is the key to economic growth (Grauwe and Zhang 2011), however, the link between human capital investment and trade openness is less developed than is the link between human capital investment and GDP growth. The primary research supporting this link was done by Contractor and Mudambi (2008). This research investigated the role of human capital investment in regards to the export competiveness of nations. Their results show that human capital investment was slightly more important to goods exports than to service exports. Additionally, they found support for their hypothesis that investment in human capital had a greater effect on developing Asian countries than it did in developed nations.

Based on the above discussion, we propose the following hypothesis.

H2 The higher the level of human capital investment in a developing economy, the higher the level of global economic integration in that economy.

\section{The Moderating Effect of Corruption}

Mauro (1996) investigated the causes and effects of corruption on economic growth, foreign investment, and government expenditures. His study focused on (1) the causes and consequences of corruption, and (2) the relationship between corruption and government expenditure. The study found corruption to have "considerable, adverse effects on economic performance". Further, and more to the point of this present work, that corruption is found to lower investment and economic growth and to reduce the share of government spending on education.

To further support his previous work, Mauro (1998) studied the composition of government expenditure in light of corruption. The primary research question was "whether predatory behavior by corrupt politicians distorts the composition of government spending." There were three primary results: (1) corruption was found to alter the composition of government spending by directing public funds to those public projects, on which it was easier to levy larger bribes and keep them secret; (2) that spending on education was found to be adversely affected by corruption; and (3) Mauro tested the direction of causality and found evidence to support a causal link from corruption to reduced spending on education. Finally, the relationship between corruption and reduced spending on education remained consistent when testing either developed or developing countries.

The focus of Akhter's (2004) research is the impact of economic globalization on human development. Additionally, he poses the relationship between economic globalization and human development is mediated by both economic freedom and corruption. He defines the economic dimension of globalization as "the increasing crosscountry integration of economic systems through trade and investments". He found evidence to support his hypothesis that economic globalization is positively related to economic freedom, which is then positively related to human development. Additionally he finds that economic globalization is negatively related to corruption, which is then negatively related to human development. Akter's primary finding is that economic globalization positively impacts human development, but that this relationship is mediated by corruption and economic freedom.

Delavallade (2006) examined the impact of corruption on the structure of government spending by sector. Her study found similar results to Mauro $(1995,1998)$ that corruption distorts the structure of public spending by increasing funds toward those projects that provide greater opportunity for bribes, such as fuel and energy and defense, and decreasing funds toward "social expenditure" such as education.

Therefore, based on the above discussion, we propose the following hypothesis.

H3 The level of perceived corruption in a developing economy will have a moderating effect on the relationship 
between human capital investment and the level of global economic integration in that economy.

\section{Methodology}

For this study, we are primarily interested in examining emerging and developing economies, and note that we collectively refer to these as developing countries. As such, we use the United Nation designations for these categories of countries (United Nations Statistical Division 2012). According to the United Nations, there exists "no established convention for the designation of "developed" and "developing" countries or areas in the United Nations system." Further from the U.N. "The designations "developed" and developing" are intended for statistical convenience and do not necessarily express a judgment about the stage reached by a particular country or area in the development process".

To test research hypotheses, we gathered data from several sources. All data are averaged over the 6-year period from 2005 to 2010. Following the reasoning from Voyer and Beamish (2004), taking the average over several years tends to account for fluctuations in the yearly data and reduces potential impacts of single year abnormalities. For this study, we excluded those developing countries with incomplete data, resulting in a sample size of 60 countries (see Appendix).

\section{Measurement of the Variables}

In our study, we use GEI as the primary dependent variable, against which we regress the independent variables: (1) human capital and (2) corruption, (3) human_capital $\times$ corruption, and (4) control variables (unemployment, labor growth rate, population (log), GDP/Capita, government consumption as a percentage of GDP, economic freedom (i.e., open markets, limited government, regulatory efficiency), and regions (i.e., East Asia and Pacific, Europe and Central Asia, Central America and Latin America, Middle East and North Africa, Sub-Saharan Africa)).

\section{Research Variables}

We use GEI as our dependent variable. To operationalize the construct of GEI, we relied on the work of, for example, Julius (1990), Akhter (2004) and Rugman and Verbeke (2004) who recommend the use of both exports and FDI to measure economic globalization. In this study we used a 6-year average (2005-2010) for both exports of goods and services per capita and for inward FDI per capita. When factor analysis was performed on these two variables, both of these variables loaded on a single factor with eigenvalue great than 1 . This factor was labeled as GEI.

Independent Variables

\section{Human Capital Investment}

Based on the existing research on human capital investment and the impact on economic growth, we measure human capital using both the level of education and government spending on education (Contractor and Mudambi 2008). To reflect the level of education, we utilize the education index (EI) produced as part of the human development index (HDI) from the United Nations Development Program (UNDP). We use the 6-year average (2005-2010). To reflect the level of government spending on education, we use government spending on education as a percent of total government spending. These data were obtained from the World Bank and averaged over the 6-year period (2005-2010 inclusive). By using the 6-year average for both variables, we remove the impact of single year abnormalities and create a variable more indicative of a county's investment in human capital. We used factor analysis on two variables to create a multidimensional construct to reflect human capital investment. Factor analysis produced a single factor with eigenvalue greater than 1 . We labeled this factor as human capital investment.

\section{Corruption}

In this study, data for measuring corruption were gathered from Transparency International's Corruption Perception Index (CPI). The CPI index is one of the most widely known and widely used measures of perceived national corruption (Habib and Zurawicki 2002; Voyer and Beamish 2004; Wilhelm 2002). The CPI index ranges from 0 (zero) to 10 (ten), with 10 indicating the lowest levels of corruption (or highly transparent country) and 0 indicating the highest levels of corruption (or least transparent country). In the current study, the CPI index represents the 6-year (2005-2010) average. This approach is supported by previous studies (Brouthers et al. 2008; Habib and $\mathrm{Zu}-$ rawicki 2002; Voyer and Beamish 2004).

Control Variables

\section{Labor Growth Rate}

We follow (Peng and Beamish 2008) in controlling for the growth in labor availability as research has shown that as the availability of cost-effective labor decreases, labor costs increase. Thus, a key factor in attracting resourceseeking FDI is the availability of competitive labor (Bartlett and Ghoshal 1988; Brouthers et al. 2008). 


\section{Unemployment}

We control for the unemployment rate. Research indicates that FDI stimulates employment at a national level by both MNE's and SME's (Billington 1999; Habib and Zurawicki 2002; Peng and Beamish 2008). Further empirical evidence suggests that lifelong learning provides a shield against unemployment (Badea and Rogojanu 2012).

\section{Population}

Regarding labor availability, a nation's population is also a factor in attracting investment. We thus follow (Arregle et al. 2013; Vaaler et al. 2008) in controlling for national level population.

\section{Regions}

In an examination of MNE investment, Rugman and Verbeke found that most MNE's are regional rather than truly global (Rugman and Verbeke 2004, 2008; Rugman 2001). Additionally, Arregle, Miller, Hitt, and Beamish reveal evidence that regional institutions have a significant influence on the country and region selection for MNE investment (Arregle et al. 2013). Using dummy variables corresponding to the regions identified by the World Bank, we control for East Asia and Pacific, Europe and Central Asia, Central and Latin America, Middle East and North Africa, and Sub-Saharan Africa.

\section{GDP per Capita}

We followed Habib and Zurawicki (2002) and Peng and Beamish (2008) research in controlling for GDP, which has been shown to be an important explanatory variable in determining the amount of inward FDI (Grosse and Trevino 1995; Kobrin 1976; Wells and Wint 2000).

\section{Government Consumption as a Percentage of GDP}

We control for host government consumption following Voyer and Beamish (2004), who indicated that market seeking FDI may be influenced by the degree of government consumption. Additionally, studies have indicated that the degree of inward FDI can be influenced by the size of the host governments' economy (Kobrin 1976; Brouthers et al. 2008).

\section{Economic Freedom}

We control for economic freedom since the level of economic freedom has been found to be a contributing factor for both economic growth (Webster 2012) and inward FDI
(Pearson et al. 2012). While several indices of economic freedom exist, we relied on economic freedom data from the Heritage Foundation's Index of Economic Freedom. However, while a single aggregate index of economic freedom has been used empirically in many studies as a measure of economic freedom in a nation, recent studies reveal that a single aggregate index may not be appropriate for operationalizing the measure (Ayal and Karras 1998; Carlsson and Lundström 2002; Haan and Siermann 1998). Thus for our study, we sought to remove the concerns associated with using a single aggregate variable. After removing freedom-from-corruption from the list of 10 economic variables gathered form the Heritage Foundation, we ran exploratory factor analysis to determine sub-indices for the remaining nine variables. We control for economic freedom by grouping the remaining nine variables into the three categories indicated by exploratory factor analysis. These three sub-indices are: (a) open markets comprised trade freedom, investment freedom, and financial freedom; (b) limited government comprised fiscal freedom and government spending; and (c) regulatory efficiency comprised business freedom, labor freedom, monetary freedom, and property rights freedom. This is consistent with the methodology used by the Heritage Foundation.

\section{Analysis and Results}

Analysis was conducted in a 2-stage process. The first stage consisted of correlation analysis (see Table 1) to identify and remove any variables that could cause problems with multicollinearity. In the second stage, the ordinary least squares (OLS) linear regression technique was employed. Here the dependent variable (GEI) was regressed against the primary independent variables (CPI, human capital investment, as well as a moderator variable human capital investment $\times$ CPI) and the control all of variables as discussed above.

Additionally, following Voyer and Beamish (2004), we tested for multicollinearity by examining the Variance Inflation Factor (VIF) for each variable. It is generally agreed that a VIF coefficient greater than 10 is indicative of severe multicolinearity (Hair 2010; Kennedy 2008; Kutner 2004). However, more stringent standards establish that a VIF level above 5 indicates severe multicollinearity. For our analysis, no single VIF is greater than 3.5. Finally, Tabachnick and Fidell, (2007) provided evidence that correlations above 0.70 could indicate issues with multicolinearity. We do not have any correlations above 0.70 between any of our independent or control variables. Hence we do not have any indication of severe multicollinearity.

To test our hypotheses, OLS regression tests were employed in a hierarchical manner in the following way: (1) the control variables only, (2) the full model with all 


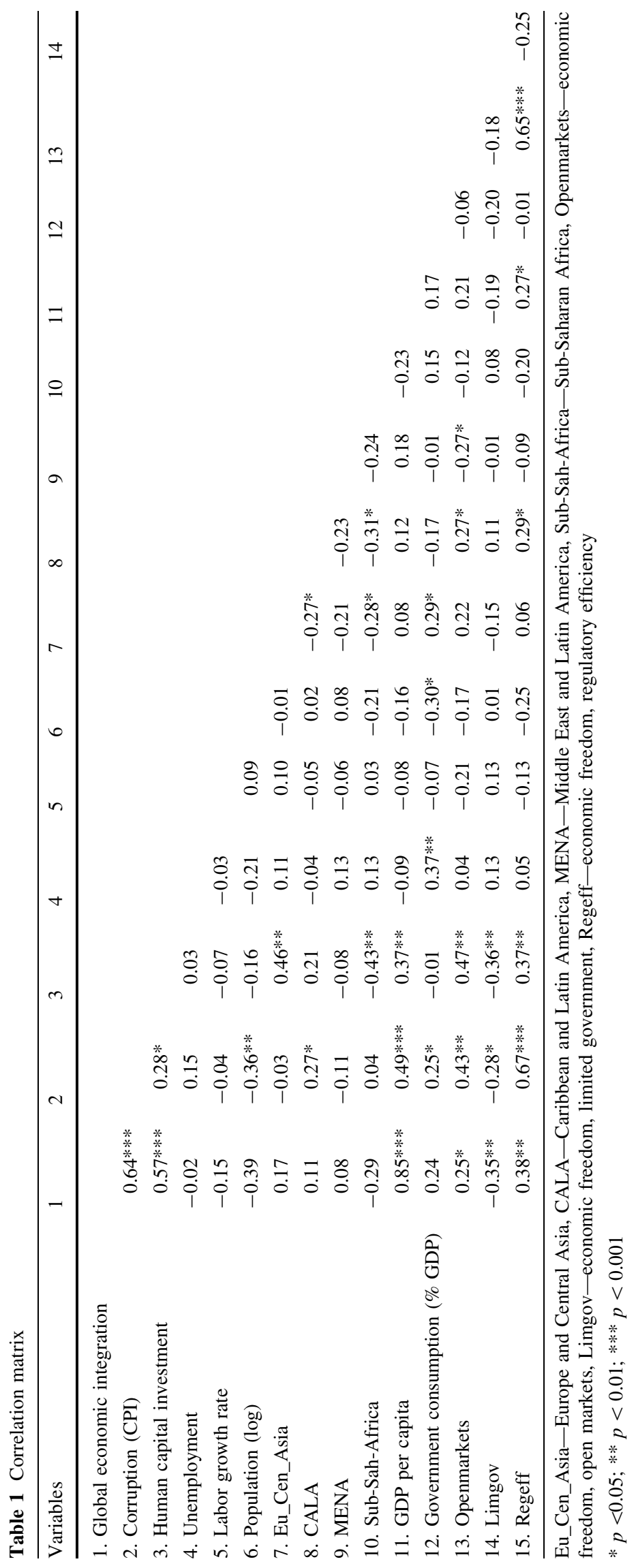


predictor variables, and (3) the full model with a moderator term.

The first model (Model 1) included only control variables: unemployment, labor growth rate, population (log), the regional dummy variables (East Asia and Pacific, Europe and central Asia, Caribbean and Latin America, Middle East and North Africa, and Sub-Saharan-Africa), GDP/capita, government consumption (\% GDP), economic freedom (openmarkets), economic freedom (limited government), and economic freedom (regulatory efficiency). Results from Model 1 (see Table 2) indicate that these control variables alone showed some explanatory power when considered as a group of indicator variables: $R^{2}=0.88$ and adjusted $R^{2}=0.85, \quad F=29.90$, $p=<0.0001$. In this model, population (log), GDP/Capita, the Sub-Sah-Africa region, and economic freedom (limgov) were significant.

The second model (Model 2) included all of the control variables from Model 1 and the two independent variables: CPI and human capital Investment. Results from Model 2 (see Table 2) indicate that the addition of the independent variables increased the overall significance of the model: $R^{2}=0.93 \quad$ and adjusted $R^{2}=0.91, \quad F=45.77$, $p=<0.0001$. In this model, both the independent variables
(CPI and Human Capital Investment) were strongly significant at the 0.001 and 0.01 level respectively.

The final model (Model 3) consisted of all of the variables from Model 2 and the moderator term (human_capital investment $\times \mathrm{CPI}$ ). Results from this model (see Table 2) are: $R^{2}=0.94$, and adjusted $R^{2}=0.92$, $F=46.48, p=<0.0001$. Also, both of the independent variables (human capital investment and CPI) as well as the moderator term (human_capital investment $\times$ CPI) were significant at $0.01,0.05$, and 0.05 respectively.

We posited in $\mathrm{H} 1$ that corruption is negatively related to GEI in developing countries. Additionally, we posited in $\mathrm{H} 2$ that for developing economies, the higher the level of human capital investment, the greater the degree of GEI. Examining the results from Model 3, the standardized $\beta$ coefficient for CPI in was 0.40 and $p=<0.0001$. Thus $\mathrm{H} 1$ is supported. The standardized $\beta$ coefficient for human capital investment is 0.57 and $p=<0.05$. Thus $\mathrm{H} 2$ is supported. Based on these results, there is evidence to indicate that country level corruption (as measured by the CPI index) and human capital investment are significant predictors of GEI. Thus we find strong support for both $\mathrm{H} 1$ and $\mathrm{H} 2$.

In $\mathrm{H} 3$, we posited that for developing countries, the level of corruption would have a moderating impact on the
Table 2 Linear regression model(s) $t$-stats in parenthesis

All $\beta$ s except constant, are standardized

$* p<0.05 ; * * p<0.001$; *** $p<0.0001$

\begin{tabular}{|c|c|c|c|}
\hline & $\begin{array}{l}\text { Model } 1 \\
\text { Control variables }\end{array}$ & $\begin{array}{l}\text { Model } 2 \\
\text { Complete model }\end{array}$ & $\begin{array}{l}\text { Model } 3 \\
\text { Moderating effects }\end{array}$ \\
\hline \multicolumn{4}{|l|}{ Controls } \\
\hline Unemployment & $0.05(0.77)$ & $-0.02(-0.41)$ & $-0.03(-0.61)$ \\
\hline Labor growth rate & $-0.06(-1.08)$ & $-0.09 *(-2.18)$ & $-0.08 *(-2.06)$ \\
\hline Population (log) & $-0.30 * * *(-5.32)$ & $-0.23 * * *(-5.12)$ & $-0.23 * * *(-5.28)$ \\
\hline Eu_Cen_Asia & $0.04(0.49)$ & $-0.02(-0.30)$ & $0.01(0.22)$ \\
\hline CALA & $0.001(-0.11)$ & $-0.10(-1.71)$ & $-0.10(-1.67)$ \\
\hline MENA & $-0.09(-1.29)$ & $-0.07(-1.35)$ & $-0.07(-1.30)$ \\
\hline Sub_Sah_Africa & $-0.18 *(-2.37)$ & $-0.21 *(-3.39)$ & $-0.19 *(-3.19)$ \\
\hline GDP per capita & $0.75 * * *(13.09)$ & $0.58 * * *(11.17)$ & $0.59 * * *(11.74)$ \\
\hline Government consumption ( $\%$ GDP) & $-0.03(-0.40)$ & $-0.02(-0.31)$ & $-0.03(-0.67)$ \\
\hline Economic freedom (open markets) & $-0.10(-1.32)$ & $-0.14 *(-2.40)$ & $-0.13 *(-3.32)$ \\
\hline Economic freedom (limited gov) & $-0.20 * *(-3.49)$ & $-0.09(-1.77)$ & $-0.11 *(-2.29)$ \\
\hline Economic freedom (regulatory eff) & $0.07(0.95)$ & $-0.09(-1.37)$ & $-0.07(-1.15)$ \\
\hline \multicolumn{4}{|l|}{ Independent variables } \\
\hline CPI & & $0.33 * * *(4.79)$ & $0.40 * * *(5.42)$ \\
\hline Human capital investment & & $0.21 * *(3.46)$ & $0.57 *(3.23)$ \\
\hline $\mathrm{HC} \times \mathrm{CPI}$ & & & $-0.42 *(-2.15)$ \\
\hline Constant & $3.14 * *(4.02)$ & $2.39 * *(3.78)$ & $2.28 * *(3.74)$ \\
\hline \multicolumn{4}{|l|}{ Model indices } \\
\hline$R^{2}$ & 0.88 & 0.93 & 0.94 \\
\hline Adjusted $R^{2}$ & 0.85 & 0.91 & 0.92 \\
\hline Model $F$ value & 29.90 & 45.77 & 46.48 \\
\hline Significance $(p)$ & $<0.0001$ & $<0.0001$ & $<0.0001$ \\
\hline Sample size & 60 & 60 & 60 \\
\hline
\end{tabular}


relationship between human capital investment and GEI. In our model, the moderator variable (human_capital investment $\times$ CPI) was indeed found to have a significant impact on the relationship between human capital investment and GEI. The standardized $\beta$ coefficient for the moderator variable was -0.42 and $p=<0.05$. Thus we find strong support for $\mathrm{H} 3$.

\section{Discussion and Implications}

Extant literature on economic growth has investigated many macroeconomic variables (FDI, GDP, national trade among them), and their respective implications for the national economy. However, as noted by (Julius 1990) single unit indicators of a national economy tend to miss the complex nature inherent within. We have attempted to fill this gap in the literature by introducing and investigating the GEI construct. As we have noted in this study, the GEI construct is a multidimensional construct developed to reflect the dynamic and complex nature of national level economic activity.

The findings of the study offer several insights into both the determinants of GEI, and the impact of national level corruption on GEI. First, we find evidence that GEI comprised mainly from exports of goods and services, and inward FDI. This is a strong indicator of national economic growth. Second, we find evidence that increased national level corruption has a negative direct impact on a country's GEI and thus, on economic growth. Third, we find that greater investments in human capital have a positive impact on a nation's GEI. Thus, we find support for all three of our hypotheses. Additionally, we find strong evidence that corruption significantly moderates the relationship between human capital investment and a nations GEI. Thus, the positive impact of an investment in human capital is somewhat dampened by national level corruption. The findings of our study support the argument made Voyer and Beamish (2004), who note that corruption is a cancer which affects all aspects of society (e.g., human capital development) and significantly debilitate a cadre of business and economic activities.

As noted by Schultz (1961), Becker (1960, 1975, 1993) and Mincer (1958), human capital investment is widely regarded as an antecedent to increased national economic activity. We empirically find support for this assertion. Also, while some researchers have noted the positive side of doing business in a corrupt economy (Dreher and Gassebner 2011), our research indicates negative direct effects of corruption on national economic activity. Finally, and of primary importance to this work, we have empirically tested the moderating effect of national level corruption on the relationship between human capital investment and
GEI. Our work provides evidence that in developing economies, corruption significantly moderates the investment in human capital-effectively removing some of the economic benefit of the investment.

Implications

The findings of this research as discussed above, not only can help in better understanding the role of corruption and human capital investment in explaining the GEI of developing economies, but also provide practical implications for leaders and policy makers of these economies. An important outcome of economic interdependence and cross-border relationships-through inward FDI and international trade, for example, has been the greater attention paid to the manner in which nations pursue their economic, political and social affairs. This has brought to light corrupt business practices prevalent within many economies, especially developing economies. We agree with Akçay (2006) who notes that "Corruption is a symptom of deep institutional weaknesses and leads to inefficient economic, social, and political outcomes. It reduces economic growth, retards long-term foreign and domestic investments, enhances inflation, depreciates national currency, reduces expenditures for education". Thus our work supports the overwhelming view of researchers that corruption in any form is treated as a disease that causes many social and economic ills and it damages the moral and ethical fibers of the society.

Corruption leads to the misallocation and inefficient use of resources, private sector development, and weakens institutions (e.g., educational institutions) that are necessary for attracting FDI and engaging in international trade activities. For developing countries to achieve greater economic interdependence, it is imperative for government leaders to develop policies that reduce corrupt practices and encourage investment in human capital development. Evidence indicates that a country with a high level of transparency in government (that is low corruption) experiences strong economic growth, more inward FDI, and more spending on such areas as improving educational institutions, training, etc. In fact, extant literature indicates that a country cannot achieve any meaningful economic growth without adequate investment in human capital via education and training.

Human capital investment is the catalyst of development for a developing country and the policy makers should lay high emphasis for the development of its human capital. Education and literacy are key components of United Nations Human Development Index. Investment in education and increasing literacy, are considered indispensable tools for transforming developing populations into productive populations (e.g., human capital) as well as for 
creating awareness among the masses about the various ills of society including the menace of high corruption.

In brief, the quality of institutions such as educational institutions and government spending on education seem to be primary factors for the economic growth of a country. Economic growth and a higher standard of living is possible when corrupt government practices are reduced and institutions such as the education system are strengthened through transparent policy making. But if the institutions are incapable of effectively enforcing policy reforms for the betterment of the society, corruption will hasten economic demise.

\section{Conclusion}

The purpose of this paper was threefold: (1) to establish GEI as a multidimensional construct comprised national export of goods and services, and inward FDI; (2) to examine the relationships between human capital investment, corruption, and GEI; and (3) to empirically study the moderating effect of national level corruption on the relationship between human capital investment and GEI.

In support of the first objective, we agree with Julius (1990), who stated that single unit indicators of a national economy tend to miss the complex nature of the overall economy. To address this oversimplification, we have introduced and tested the GEI construct to more accurately capture the complexity of an economic environment. Our results find empirical support for the idea that complex economic growth in developing countries can be partially captured by including the impact of both inward FDI and outward exports of gods and services. By establishing this construct, we have extended the existing literature by demonstrating the complex nature of a growing economy is accurately captured by a single latent construct. This finding sets the stage for more complex future research on economic growth determinants by accounting for more than just a single factor indicator (such as GDP) in reflecting economic growth.

In supporting objectives 2 and 3, this work finds that GEI is positively impacted by increased investment in human capital. Thus, our work provides additional support for the work of Mincer (1958), Schultz (1961), Becker (1960, 1975, 1993) and more recently by Effiok et al. (2012), that investment in human capital has a positive and significant effect on national economic growth.

Another important contribution of our the current research is that the pay-off for increasing investment in human capital can be significantly reduced by the level of corruption active in the public sector. Thus, a nation that adheres to human capital theory and invests heavily in developing a greater level of education can simultaneously offset the potential economic returns by permitting high levels of corruption. On the other hand, by reducing public sector corruption a country can effectively increase the efficiency of its investment in public education to produce increases in economic growth.

Finally building on strong theory and empirical studies, the results of this work have provided detailed, broad ranging implications for policy makers in developing nations. Primarily that by reducing public sector corruption developing countries can potentially increase the economic multiplier effect of investment in human capital.

\section{Appendix: Developing Countries Used in the Study}

\begin{tabular}{|c|c|}
\hline Algeria & Lithuania \\
\hline Argentina & Madagascar \\
\hline Armenia & Malaysia \\
\hline Barbados & Mauritius \\
\hline Belize & Mexico \\
\hline Botswana & Moldova \\
\hline Brazil & Mongolia \\
\hline Bulgaria & Morocco \\
\hline Burkina Faso & Namibia \\
\hline Cambodia & Paraguay \\
\hline Cameroon & Peru \\
\hline Chile & Philippines \\
\hline Colombia & Poland \\
\hline Costa Rica & Romania \\
\hline Dominican Republic & Russian Federation \\
\hline Egypt, Arab Rep. & Saudi Arabia \\
\hline El Salvador & Senegal \\
\hline Ethiopia & Serbia \\
\hline Georgia & Seychelles \\
\hline Ghana & St. Lucia \\
\hline Hungary & Syrian Arab Republic \\
\hline Indonesia & Tanzania \\
\hline Jamaica & Thailand \\
\hline Kuwait & Tunisia \\
\hline Kyrgyz Republic & Uganda \\
\hline Lao PDR & Ukraine \\
\hline Latvia & Uruguay \\
\hline Lebanon & Vanuatu \\
\hline Lesotho & Vietnam \\
\hline Liberia & Yemen, Rep. \\
\hline
\end{tabular}

\section{References}

Akçay, S. (2006). Corruption and human development. CATO Journal, 26(1), 29-48.

Akhter, S. H. (2004). Is globalization what it's cracked up to be? Economic freedom, corruption, and human development. Journal of World Business, 39, 283-295. 
Akinola, G. O. (2012). Effect of globalization on performance in the Nigerian Banking Industry. International Journal of Management and Marketing Research, 5(1), 79-95.

Al-Sadig, A. (2009). The effects of corruption on FDI inflows. CATO Journal, 29(2), 267-294.

Arregle, J.-L., Miller, T., Hitt, M., \& Beamish, P. W. (2013). Do regions matter? An integrated institutional and semiglobalization perspective on the internationalization of MNE's. Strategic Management Journal, 34, 910-934. doi:10.1002/smj.

Ayal, E. B., \& Karras, G. (1998). Components of economic freedom and growth: An empirical study. Journal of Developing Areas, 32(3), 327-338.

Badea, L., \& Rogojanu, A. (2012). Controversies concerning the connection higher education-human capital-competitiveness. Theoretical and Applied Economics, XIX(12), 125-142.

Bain, J. (1956). Barriers to new competition. Their character and consequences in manufacturing industries (p. 339). Harvard University Press.

Bartlett, Ca., \& Ghoshal, S. (1988). Organizing for worldwide effectiveness: The transnational solution. California Management Review, 31(1), 54-74. doi:10.2307/41166538.

Becker, G. S. (1960). Underinvestment in college education? American Economic Review, 50(2), 346-354.

Becker, G. S. (1975). Investment in human capital: Effects on earnings. In Human capital: A theoretical and empirical analysis, with special reference to education (2nd ed., Vol. I, pp. 13-44). New York: NBER.

Becker, G. S. (1993). Human capital: A theoretical and empirical analysis, with special reference to education (2nd ed., pp. 1-187). Chicago: The University of Chicago Press.

Billington, N. (1999). The location of foreign direct investment : An empirical analysis. Applied Economics, 31, 65-76.

Boddewyn, J. J. (1988). Political aspects of MNE theory. Journal of International Business Studies, 19(3), 341-363.

Brouthers, L. E., Gao, Y. A. N., \& McNicol, J. P. (2008). Corruption and market attractiveness influences on different types of FDI. Strategic Management Journal, 29, 673-680.

Calomiris, C. (2000). When will Economics Guide IMF and World Bank reforms. CATO Journal, 20(1), 85-103.

Carlsson, F., \& Lundström, S. (2002). Economic freedom and growth: Decomposing the effects. Public Choice, 112, 335-344.

Chang, C.-P., \& Lee, C.-C. (2011). The effect of globalization and political party on economic growth. Eastern European Economics, 49(6), 5-26.

Coase, R. H. (1937). The nature of the firm. Economica, 4(16), 386-405.

Contractor, F. J., \& Mudambi, S. M. (2008). The influence of human capital investment on the exports of services and goods: An analysis of THE Top 25 services outsourcing countries. Management International Review, 48(4), 433-445.

DE Haan, J., \& Siermann, C. L. J. (1998). Further evidence on the relationship between economic freedom and economic growth. Public Choice, 95, 363-380.

Delavallade, B. C. (2006). Corruption and distribution of public spending in developing countries. Journal of Economics and Finance, 30(2), 222-239.

Delios, A., Mudambi, R., \& Navarra, P. (2006). Corruption and FDI: Japanese FDI inflows into the EU, 1996-2002. In L. Oxelheim (Ed.), Corporate and institutional transparency for economic growth in Europe (1st ed., pp. 399-415). Amsterdam: Elsevier.

Dollar, D. (1992). Outward-oriented developing economies really do grow more rapidly: Evidence from 95 LCD's, 1976-1985. Economic Development and Cultural Change, 40(3), 523-544.

Dreher, A., \& Gassebner, M. (2011). Greasing the wheels? The impact of regulations and corruption on firm entry. Public Choice, 155(3-4), 413-432.
Dunning, J. H. (1980). Toward an eclectic theory of international production: Some empirical tests. Journal of International Business Studies, 11, 9-31.

Dunning, J. H. (1988). The eclectic paradigm of international production: A restatement and some possible extensions. Journal of International Business Studies, 19(1), 1-31.

Dunning, J. H. (1993). How should national governments respond to globalization? International Executive, 35(3), 187-198.

Dunning, John. H., \& Rugman, A. M. (1985). The influence of Hymer's dissertation on the theory of foreign direct investment. American Economic Review, 75, 228-232.

Effiok, S. O., Tapang, A. T., \& Eton, O. E. (2012). The impact of human capital cost on gross domestic product (GDP) in Nigeria. International Journal of Financial Research, 3(4), 116-127.

Galor, O., \& Moav, O. (2004). From physical to human capital accumulation: Inequality and the process of development. Review of Economic Studies, 71(4), 1001-1026.

Glaeser, E. L., La Porta, R., Lopez-de-Silanes, F., \& Shleifer, A. (2004). Do institutions cause growth? Journal of Economic Growth, 9(3), 271-303.

Grauwe, P. De., \& Zhang, Z. (2011). Globalisation and economic integration in East Asia. International Journal of Business Studies, 19(1), 1-6.

Grosse, R., \& Trevino, L. J. (1995). Foreign direct investment in the United States: An analysis by country of origin. Journal of International Business Studies, 27(1), 139-155.

Habib, M., \& Zurawicki, L. (2002). Corruption and foreign direct investment. Journal of International Business Studies, 33(2), 291-307.

Hair, J. F. (2010). Multivariate data analysis (7th ed., p. 785). Upper Saddle River, NJ: Prentice Hall.

Harris, R. G. (1993). Globalization trade and income. Canadian Journal of Economics, 26(4), 755-776.

Hines, J. (1995). Forbidden payment: Foreign bribery and American business after 1977. NBER Working Paper No. 5266. Cambridge, MA: National Bureau of Economic Research.

Holm, H., \& Sorenson, G. (1995). Whose world order? Uneven globalization and the end of cold war. Boulder, CO: Westview Press.

Hymer, S. (1976). The International Operations of National Firms: A study in direct foreign investment (p. 253). Cambridge, MA: MIT Press.

Julius, D. (1990). Global companies \& public policy: The growing challenge of foreign direct investment (pp. 1-126). New York: Council on Foreign Relations Press, Royal Institute of International Affairs.

Kennedy, P. (2008). A guide to econometrics (6th ed., p. 585). Malden, MA: Blackwell.

Kobrin, S. J. (1976). The environmental determinants of foreign direct manufacturing investment: An ex-post empirical analysis. Journal of International Business Studies, 7(2), 29-42.

Kutner, M. H., Nachtsheim, C. J., \& Neter, J. (2004). Applied linear regression models (4th ed., p. 701). Boston: McGraw-Hill.

Lee, J.-W. (1995). Capital goods imports and long-run growth. Journal of Development Economics, 48(1), 91-110.

Lucas, R. E. (1988). On the mechanics of economic development. Journal of Monetary Economics, 22, 3-42.

Maizels, A. (1968). Exports and growth in developing countries. London: Cambridge University Press.

Malnight, T. W. (1995). Globalization of an ethnocentric firm: An evolutionary perspective. Strategic Management Journal, 16, $119-141$.

Mauro, P. (1995). Corruption and growth. Quarterly Journal of Economics, 110(3), 681-712.

Mauro, P. (1996). The effects of corruption on growth, investment, and government expenditure. IMF Working Papers 96/98. International Monetary Fund, pp. 1-28. 
Mauro, P. (1997). Why worry about corruption? (Vol. 6, pp. 1-19). Washington, DC: International Monetary Fund.

Mauro, P. (1998). Corruption and the composition of government expenditure. Journal of Public Economics, 69(2), 263-279.

Meltzer, A. H. (2000). The Report of the International Financial Institution Advisory Commission: Comments on the critics. Tepper School of Business Paper, 29, 1-14.

Mikesell, R. F. (2001). Review article: The Meltzer Commission Report on international institutions. Economic Development and Cultural Change, 49(4), 883-894.

Mincer, J. (1958). Investment in human capital and personal income distribution. The Journal of Political Economy, 66(4), 281-302.

Morrison, A., \& Roth, K. (1992). A taxonomy of business-level strategies in global industries. Strategic Management Journal, 13(6), 399-418.

O'Mahony, M. (2012). Human Capital formation and continuous training: evidence for EU countries. Review of Income and Wealth, 58(3), 531-549.

Olimpia, N. (2010). The market value of human capital: An empirical analysis. In The Annals of the University of Oradea (pp. 256-265).

Pearson, D., Nyonna, D., \& Kim, K.-J. (2012). The Relationship between economic freedom, state growth and foreign direct investment in US States. International Journal of Economics and Finance, 4(10), 140-147.

Peng, G. Z., \& Beamish, P. W. (2008). The effect of national corporate responsibility environment on Japanese Foreign Direct Investment. Journal of Business Ethics, 80, 677-695.

Pigou, A. C. (1928). A study in public finance (pp. 1-325). London: Macmillan.

Porter, M. E. (1986). Competition in global industries (pp. 1-592). Boston: Harvard Business School Press.

Robertson Christopher, J., \& Watson, A. (2004). Corruption and change: The impact of foreign direct investment. Strategic Management Journal, 25, 385-396.

Rugman, A. M. (2001). The myth of global strategy. International Marketing Review, 18(6), 583-588.

Rugman, A. M., \& Verbeke, A. (2004). A perspective on regional and global strategies of multinational enterprises. Journal of International Business Studies, 35(1), 3-18.

Rugman, A. M., \& Verbeke, A. (2008). A regional solution to the strategy and structure of multinationals. European Management Journal, 26(5), 305-313. doi:10.1016/j.emj.2008.04.004.

Sachs, J. (2000, May/June). Glorifying Mediocrity. The International Economy, pp. 14-16.
Schultz, T. W. (1961). Investment in human capital. The American Economic Review, 51(1), 1-17.

Sorensen, A. (2002). Value, business and globalisation-Sketching a critical conceptual framework. Journal of Business Ethics, 39, 161-167.

Sweetland, S. R. (1996). Human capital theory: Foundations of a field of inquiry. Review of Educational Research, 66(3), 341-359.

Tabachnick, B. G., \& Fidell, L. S. (2007). Using multivariate statistics (5th ed., p. 1008). Boston: Allyn \& Bacon.

Transparency-International. (2010). How do you define corruption. Retrieved from http://archive.transparency.org/news_room/faq/ corruption_faq.

United Nations Statistical Division. (2012). Standard country or area codes and geographical regions for statistical use. Retrieved from http://unstats.un.org/unsd/methods/m49/m49.htm.

Vaaler, P. M., Esfahani, H., Hoetker, G., Kraatz, M., Leb, D., Mahoney, J., \& Riley, S. (2008). How do MNC's vote in developing country elections? Academy of Management Journal, 51(1), 21-43.

Voyer, P. A., \& Beamish, P. W. (2004). The effect of corruption on japanese foreign direct investment. Journal of Business Ethics, $50(3), 211-224$.

Wagner, J. (2007). Exports and productivity: A survey of the evidence from firm-level data. The World Economy, 30(1), 60-82.

Webster, A. L. (2012). Levels of economic freedom and their impact on rates of economic growth: Using panel data, 2000-2009. Economics and Finance Review, 2(1), 01-09.

Wei, S.-J. (2000). How taxing is corruption on international investors. Review of Economics and Statistics, 82(1), 1-11.

Weithöner, T. (2006). How can IMF policy eliminate country moral hazard and account for externalities? Journal of International Money and Finance, 25, 1257-1276. doi:10.1016/j.jimonfin. 2006.09.009.

Wells, L. T., \& Wint, A. G. (2000). Marketing a country: Promotion as a tool for attracting foreign direct investment (pp. 1-204). Washington, DC: World Bank.

Wheeler, D., \& Mody, A. (1992). International decisions investment location: The case of U.S. firms. Journal of International Economics, 33, 57-76.

Wilhelm, P. G. (2002). International validation of the corruption perceptions index: Implications for business ethics and entrepreneurship education. Journal of Business Ethics, 35, 177-189.

$\mathrm{Wu}$, S.-Y. (2006). Corruption and cross-border investment by multinational firms. Journal of Comparative Economics, 34, 839-856. 